\title{
Kontaminasi Telur Soil Transmitted Helminth pada Sayur Selada (Lactuca sativa) di Pasar Tradisional
}

\section{Contamination of Soil Transmitted Helminth Eggs in Lettuce (Lactuca sativa) in Traditional Markets}

\author{
Hebert Adrianto \\ Departemen Parasitologi Fakultas Kedokteran Universitas Ciputra Surabaya
}

\begin{abstract}
ABSTRAK
Makanan cepat saji dengan sayur segar mentah (lalapan) banyak ditemui di Surabaya yang berpotensi menjadi sumber kontaminasi telur cacing Soil Transmitted Helminths (STH). Tujuan penelitian ini adalah untuk mengetahui distribusi dan angka kontaminasi telur cacing STH pada sayur selada yang dijual di pasar tradisional di Surabaya. Survei dilakukan dengan objek sayur selada yang diambil dari enam pasar di Surabaya. Identifikasi cacing dilakukan di laboratorium parasitologi menggunakan metode sedimentasi. Data kontaminasi disajikan dalam bentuk tabel distribusi frekuensi. Pada pemeriksaan ditemukan tanah yang menempel pada daun sayur selada. Sebanyak $61,90 \%$ penjual menjual selada yang positif mengandung telur cacing. Telur cacing STH yang ditemukan hanya telur cacing Ascaris spp dengan proporsi temuan kontaminasi menurut penjual bervariasi mulai dari $25 \%$ hingga $100 \%$ jika dibagi menurut wilayah pasar. Penelitian ini membuktikan adanya kontaminasi telur cacing Ascaris spp pada sebagian besar penjual sayur selada di pasar tradisional Surabaya.
\end{abstract}

Kata Kunci: Ascaris spp., pasar tradisional, selada

\section{ABSTRACT}

Fast food with fresh raw vegetables which can be easily found in Surabaya has a potential to be the source of contamination of Soil Transmitted Helminth (STH) eggs. This research aimed to know the distribution and the number of STH egg contamination on lettuce sold in traditional markets in Surabaya. The survey was conducted by taking lettuce from six markets in Surabaya as samples. Worm identification was done in a parasitology laboratory using sedimentation method. Contamination data is presented in a form of frequency distribution tables. On the examination, soil was found attached to the lettuce leaves. As many as $61.90 \%$ of sellers sell lettuce that positively contained worm eggs. STH eggs found were only Ascaris spp eggs with a proportion of contaminant findings based on sellers vary from $25 \%$ to $100 \%$ if divided by market region. This study proves the presence of Ascaris spp worm egg contamination in most of the lettuce sold in traditional markets in Surabaya.

Keywords: Ascaris spp., lettuce, traditional market

Korespondensi: Hebert Adrianto. Departemen Parasitologi Fakultas Kedokteran Universitas Ciputra Surabaya, UC Town, Waterpark Boulevard, CitraLand CBD, Surabaya60219Tel. (031) 7451699/081235245620Email: hebert.rubay@ciputra.ac.id

DOI: http://dx.doi.org/10.21776/ub.jkb.2018.030.02.16 


\section{PENDAHULUAN}

Permasalahan penyakit akibat cacing Soil Transmitted Helminths (STH) masih banyak ditemukan di negara tropis termasuk Indonesia dan belum dituntaskan (1). Rahmawati dkk, menyebutkan bahwa prevalensi kecacingan di Surabaya tercatat masih cukup tinggi yaitu sekitar 36\% (2). Anak balita, anak usia sekolah (5-15 tahun) serta ibu hamil adalah kelompok yang berisiko tinggi terinfeksi STH $(1,3,4)$. Parasit cacing yang sering ditemukan mengkontaminasi sayuran mentah adalah cacing STH yaitu kelompok cacing yang ditularkan melalui tanah, meliputi Ascaris lumbricoides (cacing gelang), Trichuris trichiura (cacing cambuk), cacing tambang (Ancylostoma duodenale dan Necator americanus) (5).

Surabaya adalah ibu kota Provinsi Jawa Timur dan kota terbesar di Indonesia dengan jumlah penduduk terbanyak ke dua di Indonesia sebesar 2.848.583 jiwa (6), dan mempunyai potensi wisata dan usaha kuliner. Ketua DPD Asosiasi Pengusaha Kafe dan Restoran Indonesia (Apkrindo) Jawa Timur, Tjahjono Haryono menyebutkan ada 2.000 usaha kuliner di Surabaya (7). Masyarakat kota Surabaya sekarang memiliki gaya hidup makan di luar rumah sehingga menjadi peluang bisnis kuliner dalam menawarkan banyak variasi makanan cepat saji (8). Jenis makanan yang akan dibeli oleh konsumen secara tidak langsung akan mempengaruhi kesehatan.

Sayur selada (Lactuca sativa) adalah sayur yang sering ditemukan pada makanan yang dijual pada masyarakat kota, baik makanan khas Indonesia maupun internasional yang dikonsumsi dalam kondisi mentah. Makanan cepat saji dengan sayur segar mentah (lalapan) banyak ditemui di Surabaya, sebagai contoh mie ayam, gado-gado, tahu campur, hamburger, salad, ayam dan ikan bakar yang memakai sayur selada (Lactuca sativa) (5). Sayur selada lebih sering dikonsumsi dalam keadaan segar dan mentah sebab a pabila dimasak teksturnya akan menjadi lebih liat.

Kondisi pertumbuhan sayur selada mempunyai risiko kontaminasi oleh cacing. Sayur selada tumbuh pada posisi duduk, dengan daun berkontak langsung dengan tanah sehingga meningkatkan risiko penularan cacing STH. Penelitian terdahulu menyatakan bahwa selada yang dijual di Pasar Tradisional di Kota Padang ditemukan telur Ascaris sp (79\%) dan telur cacing tambang (5\%) (5). Di Vietnam juga dilaporkan ditemukan telur Ascaris (88,89\%) dan Trichuris (66,67\%) (9). Penelitian ini dilakukan untuk mengkaji prevalensi kontaminasi cacing STH pada sayur selada yang dijual di pasar tradisional di kota Surabaya. Hasil penelitian diharapkan dapat menjadi dasar dalam mengelola kebersihan bahan pangan dalam rantai distribusi makanan.

\section{METODE}

Penelitian ini merupakan penelitian deskriptif dengan sampel penelitian adalah sayur selada dari enam pasar tradisional pada empat wilayah di Surabaya. Setiap pasar diambil 4 orang penjual selada yang ditetapkan peneliti. Apabila di suatu pasar didapatkan kurang dari 4 penjual maka seluruh penjual yang ada tersebut dilibatkan dalam penelitian. Pada masing-masing penjual diambil 4 sayuran selada. Pemeriksaan cacing STH dilakukan di Laboratorium Parasitologi Fakultas Kedokteran Universitas Ciputra. Metode yang digunakan dalam memeriksa telur cacing pada sayur selada adalah metode sedimentasi (pengendapan).
Sampel sayur selada yang diambil dimasukkan ke dalam kantong plastik dan diberi label nama pasar dan nomor penjual, lalu dibawa ke laboratorium. Potongan sayur selada direndam dalam larutan $\mathrm{NaOH} 0,2 \%$ selama 30 menit. Selanjutnya selada diangkat dan larutan rendaman dimasukkan ke dalam tabung sedimentasi kemudian didiamkan selama satu jam. Larutan bagian atas dibuang dan disisakan 10-15ml kemudian dimasukkan ke dalam tabung sentrifugasi untuk disentrifus dengan kecepatan 1.500rpm selama 5 menit. Supernatan dibuang dan endapan bagian bawah diambil lalu dituangkan di objek glass. Sedimen diteteskan dengan reagen iodin lugol kemudian ditutup dengan cover glass (cairan harus merata dan tidak ada gelembung udara). Dilakukan pemeriksaan mikroskopis dengan perbesaran 40-400x. Data disajikan dalam bentuk tabel distribusi frekuensi.

\section{HASIL}

Sayur selada yang diperoleh dari enam pasar tradisional di kota Surabaya tidak semuanya dalam keadaan bersih. Pada beberapa sayur selada masih ditemukan tanah yang menempel di pangkal daun, tangkai daun, dan lembaran daun (Gambar 1).

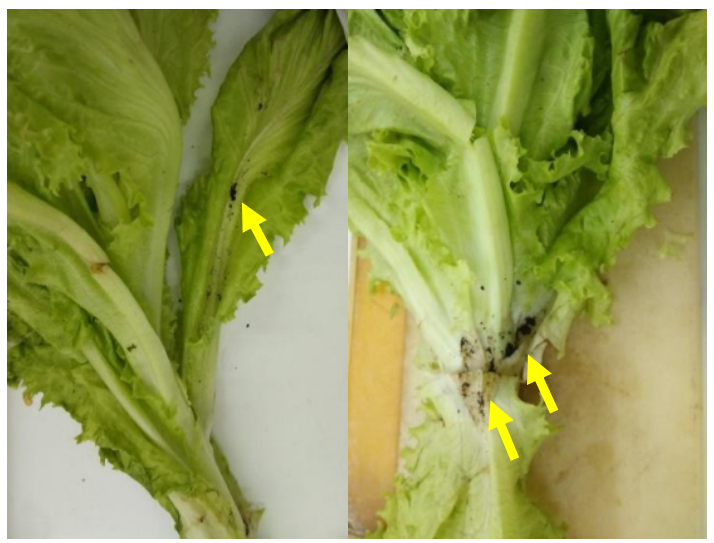

Gambar 1. Kotoran tanah pada selada.

Keterangan: Tanda panah berwarna kuning = tanah

Dalam penelitian ini hanya ditemukan satu spesies telur cacing yaitu telur Ascaris spp. Sayur yang diambil dari empat penjual pasar A ditemukan semuanya positif mengandung telur cacing Ascaris spp. Jumlah telur Ascaris spp. tertinggi ditemukan pada pasar B sebesar $42,5 \%$ dan kontaminasi terendah sebesar $5 \%$ didapatkan pada pasar $\mathrm{E}$ di Surabaya Timur (Tabel 1). Berdasarkan wilayah, proporsi penjual dengan sayur selada positif mengandung telur cacing Ascaris spp yang terbesar pada wilayah Surabaya pusat $(100 \%)$, dan yang paling kecil di Surabaya timur (25\%). Secara keseluruhan jumlah penjual dengan sayur terkontaminasi telur cacing Ascaris spp sebesar 13 (61,9\%).

\section{DISKUSI}

Parasit cacing yang ditemukan pada sayur selada di enam pasar tradisional di kota Surabaya pada penelitian ini hanya ada satu spesies, yaitu cacing Ascaris spp. stadium telur. Temuan serupa juga didapatkan pada penelitian di Semarang, Nigeria, Ethiopia meskipun dengan jenis sayur yang berbeda (kubis, cabai, bayam) (10-12). Fagbenro et al. 
Tabel 1. Distribusi telur cacing Ascaris spp. pada sayur selada di pasar tradisional di kota Surabaya

\begin{tabular}{|c|c|c|c|c|c|c|}
\hline Wilayah & Pasar & $\begin{array}{l}\text { Jumlah } \\
\text { penjual }\end{array}$ & $\begin{array}{c}\text { Penjual dengan sayur } \\
\text { mengandung telur } \\
\text { Ascaris spp }\end{array}$ & $\begin{array}{l}\text { Prosentase penjual dengan } \\
\text { sayur terkontaminasi telur } \\
\text { Ascaris spp per wilayah }\end{array}$ & $\begin{array}{c}\text { Rerata } \\
\text { jumlah telur } \\
\text { Ascaris spp. }\end{array}$ & $\begin{array}{c}\text { Prosentase jumlah } \\
\text { telur Ascaris spp. } \\
(\%)\end{array}$ \\
\hline Pusat & $A$ & 4 & 4 & 100 & 12 & 30 \\
\hline \multirow[t]{2}{*}{ Barat } & B & 3 & 3 & 80 & 17 & 42.5 \\
\hline & $\mathrm{C}$ & 2 & 1 & & 2 & 5 \\
\hline Selatan & $\mathrm{D}$ & 4 & 3 & 75 & 6 & 15 \\
\hline \multirow[t]{2}{*}{ Timur } & $E$ & 4 & 2 & 25 & 3 & 7.5 \\
\hline & $\mathrm{F}$ & 4 & 0 & & 0 & 0 \\
\hline Total & & 21 & 13 & & 40 & 100 \\
\hline
\end{tabular}

menemukan bahwa cacing Ascaris lumbricoides lebih mendominasi dan banyak ditemukan pada sayur di Nigeria dengan angka prevalensi lebih tinggi, yaitu sebesar $68,6 \%$ (13). Pada 12 spesies sayuran yang diperoleh dari pasar tradisional di kota Hue, Vietnam dilaporkan telur cacing yang paling banyak ditemukan adalah telur Ascaris (85\%) (9). Angka prevalensi cacing Ascaris yang rendah ditemukan dalam penelitian Eraky et al., yaitu sebesar $0,6 \%$ pada lima spesies sayur yang diteliti (14). Parasit lainnya yang ditemukan pada studi oleh Benti et al., berasal dari kelompok protozoa (hewan bersel satu), yaitu G. intestinalis dan E. histolytica (12).

Jumlah penjual yang menjual sayur selada dan positif mengandung telur cacing pada penelitian ini sebanyak 13 dari 21 orang (61,9\%). Jumlah telur cacing Ascaris spp. pada sayur selada di enam pasar tradisional Surabaya beragam mulai dari terendah $5 \%$ hingga $42,5 \%$. Proporsi ini lebih tinggi dibandingkan penelitian Lobo dkk yang menemukan 46,4\% dari 28 pedagang sayur selada di Palu Barat memiliki sayur yang terkontaminasi parasit (15). Demikian juga penelitian yang dilakukan terhadap 26 pedagang pecel lele di Kota Yogyakarta mengidentifikasi 6 pedagang $(23,1 \%)$ dengan kubis terkontaminasi telur cacing (16).

Cacing Ascaris lumbricoides memiliki persebaran geografi yang sangat luas di dunia dan merupakan penyebab utama penyakit kecacingan pada manusia di negara tropis dan subtropis hingga sekarang (17). Infeksi parasit yang paling tinggi ditemukan di dunia adalah Ascaris (20\%), sedangkan Hookworm, Trichuris trichiura, dan Entamoeba histolytica masing-masing sebesar 18\%, 10\%, dan 10\% (18). Penelitian Anbumani dan Mallika menemukan prevalensi infeksi cacing Ascaris pada anak-anak sekolah di Tamil Nadu, India sebesar $60 \%$ lebih tinggi, diikuti T. trichira yang hanya $4,17 \%$ (18). Demikian pula penelitian yang dilakukan pada peternak di Ampenan Selatan, kota Mataram, Provinsi Nusa Tenggara Barat paling banyak terinfeksi cacing Ascaris lumbricoides (80\%) (19).

Hanya ditemukannya telur Ascaris dalam sayur selada pada penelitian ini berbeda dengan penelitian Chau et al., yang menemukan kontaminasi telur Fasciola $(77,78 \%)$, telur Trichuris $(66,67 \%)$, telur Clonorchis sinensis (33,33\%), ookista Cryptosporidium (55,56\%), ookista Cyclospora (22,22\%), dan ookista Isospora (33,33\%) disamping Ascaris pada sayur selada (9). Penelitian Benti dan Gemechu juga melaporkan ditemukan telur cacing $A$. lumbricoides, kista $G$. Intestinalis, dan kista $E$. histolytica pada sayur selada di Ethiopia (12). Tefera et al., juga melaporkan adanya parasit Strongyloides, Toxocara spp, Cryptosporidium spp, H. nana, G. Lamblia, A. lumbricoides, E. histolytica, Cyclospora spp, dan $H$. diminuta (20). Perbedaan hasil ini dapat disebabkan karena faktor lingkungan yang berbeda, endemisitas penyakit parasit di setiap negara, status ekonomi dan sosial, perilaku higienis dari individu, serta sistem persawahan dan pengairan $(9,12,13)$. Selain itu jenis pewarnaan tertentu yang dapat mendeteksi spesifik parasit tertentu juga dapat menentukan penemuan parasit, seperti pewarnaan Zeihl-Neelsen modifikasi untuk mewarnai kista Cryptosporidium, Isospora, dan Cyclospora $(14,20,21)$.

Pemilihan sayur selada dalam penelitian ini dibandingkan sayur lainnya dikarenakan banyak penelitian terdahulu yang mengemukakan bahwa sayur selada paling tinggi terkontaminasi parasit cacing. Olyaei et al., menyebutkan bahwa selada terkontaminasi parasit paling tinggi $(86,7 \%)$ dibandingkan delapan sayur lainnya (22). Alsubaie et al. juga menemukan bahwa kontaminasi parasit yang tinggi ada pada sayur selada (33,3\%) dibandingkan sayur lobak, bawang perai, dan bawang hijau (23). Dua puluh lima dari 45 sayur selada $(55,6 \%)$ yang didapatkan dari pasar di kota Jimma, Ethiopia positif mengandung telur cacing (20). Di Mesir juga dilaporkan 101 sayur selada (lettuce) terkontaminasi telur cacing sebesar 46\% (14).

Spesies Ascaris spp. yang ditemukan pada penelitian ini belum bisa dipastikan adalah spesies Ascaris lumbricoides, terlebih lagi banyak telur cacing dari hospes di dalam sayur, baik itu manusia, hewan, maupun lainnya. Penulis menemukan beberapa hasil penelitian yang menyebutkan bahwa genus Ascaris terdiri dari beberapa spesies yaitu Ascaris lumbricoides dengan hospes definitifnya adalah manusia, Ascaris suum yang lazim terdapat pada babi namun dapat menyebabkan creeping eruption pada manusia, dan Ascaris vitulorum yang terdapat pada sapi, kambing maupun domba (5). Banyak penulisan cacing Ascaris diakhiri dengan spp., sebagai contoh penelitian yang ditemukan adalah Asihka dkk, menemukan adanya telur Ascaris spp. pada sayur selada yang dijual di pasar tradisional dan pasar modern di kota Padang (5). Sunil et al., juga menemukan adanya telur Ascaris spp. pada cabai dan bawang (21). Di lain sisi Leles et al., dan Liu et al., menyebutkan bahwa Ascaris lumbricoides sama dengan Ascaris suum $(24,25)$. Ascaris suum dipertimbangkan sebagai sinonim dari Ascaris lumbricoides sedangkan Ascaris vitulorum belum diungkapkan.

Pencemaran telur cacing pada sayur selada oleh manusia dapat disebabkan struktur sayur dan proses produksi hingga distribusi. Sayur selada yang sangat pendek menyebabkan terjadi kontak dengan tanah sehingga mudah tercemar. Telur cacing Ascaris dapat masuk ke tubuh manusia melalui sayuran yang terkontaminasi tanah yang mengandung telur cacing $(12,13)$. Penelitian 
Fagbenro mengungkapkan dari 18 penjual (responden), hanya 1 orang penjual yang tidak mencuci sayur sebelum dijual ke konsumen (13). Meskipun demikian dari 102 sampel sayur yang diuji, sayur yang terkontaminasi tetap tinggi yaitu $75 \%$. Perbedaan pemasok sayur juga kemungkinan ikut berpengaruh.

Pada saat dilakukan pemeriksaan telur cacing, ditemukan tanah yang menempel pada sayur selada di bagian lembaran daun, tangkai daun, dan pangkal daun. Selada merupakan tanaman berumpun banyak, berdaun lebar, panjang daun sekitar $20-25 \mathrm{~cm}$ dan lebar $15 \mathrm{~cm}$. Suhu yang untuk produksi selada berkualitas tinggi adalah $20^{\circ} \mathrm{C}(26)$. Batang sayur selada pendek sehingga daunnya dapat kontak dengan tanah. Adanya tanah yang menempel pada daun selada menjadi faktor risiko penularan parasit cacing usus $(9,15,27)$. Habitat dan siklus cacing Ascaris memerlukan media tanah liat/gembur $(15,28)$. Penggunaan pupuk dari tinja juga dapat menjadi media perantara penularan cacing Ascaris $(11,13,16)$. Telur Ascaris bersifat tahan terhadap desinfektan kimia dan dapat hidup berbulan-bulan di dalam tinja $(15,16)$. Angka kepadatan telur parasit pada setiap bagian daun memunculkan peluang penelitian ke depannya untuk diteliti lebih dalam.

Upaya pencegahan yang dapat dilakukan agar sayur selada tidak mengandung telur cacing adalah mencuci dengan air mengalir dan sayur dicuci lembar per lembar $(15,16,28)$. Mencuci sayur hanya di bagian luar tidak akan dapat mengurangi tingkat kontaminasi telur cacing (16). Suryani (16) menyebutkan bahwa mencuci sayur dengan baskom, tidak dengan air mengalir, dan air tidak diganti

\section{DAFTAR PUSTAKA}

1. Mukhasin N, Wahyuni S, Ilyas F, Amin S, Satriono R, dan Tabri F. Infeksi Cacing Tidak Berpengaruh terhadap Kadar Transforming Growth Factor (TGF)-6 dan Kejadian Dermatitis Atopik pada Anak. Jurnal Kedokteran Brawijaya. 2015; 28(3): 217-221.

2. Rahmawati, Soeyoko, dan Sumarni S. Hygiene, Sanitation and The Soil Transmitted Helminths (STH) Infection Among Elementary School Students in West Lombok. Journal of The Medical Science. 2014; 46(2): 94-101.

3. Getachew M, Tafess K, Zeynudin A, and Yewhalaw D. Prevalence Soil Transmitted Helminthiasis and Malaria Co-infection Among Pregnant Women and Risk Factors in Gilgel Gibe dam Area, Southwest Ethiopia. BioMed Central Research Notes. 2013; 6(263): 1-8.

4. Emana D, Jemal K, Bajiro M, and Mekonnen Z. Prevalence and Intensity of Soil-Transmitted Helminths Among School-Aged Children in Sigmo Primary School. Clinical Medicine Research. 2015; 4(4): 98-103.

5. Asihka V, Nurhayati, dan Gayatri. Distribusi Frekuensi Soil Transmitted Helminth pada Sayuran Selada (Lactuca sativa) yang Dijual di Pasar Tradisional dan Pasar Modern di Kota Padang. Jurnal Kesehatan Andalas. 2013; 3(3): 480-485.

6. Dinas Kesehatan Surabaya. Profil Kesehatan Kota Surabaya Tahun 2015. Surabaya: Dinas Kesehatan dalam proses mencuci meningkatkan peluang telur cacing menempel lagi di sayur. Selain itu juga dilaporkan dalam proses transportasi selada dari satu tempat ke tempat lain untuk dijual selalu disiram dengan air sungai atau selokan agar tidak layu $(9,16,21)$. Jarang sayur selada dimasak matang karena akan berakibat liat dan rasa kurang enak (15) sehingga satu-satunya cara pencegahan telur STH pada sayur selada adalah mencuci dengan benar. Untuk ke depannya, pengusaha kuliner dan ibu rumah tangga yang membeli sayur selada harus lebih waspada dan mencuci sayur selada dengan benar.

Berdasarkan hasil penelitian ini dapat disimpulkan bahwa telur cacing Soil Transmitted Helminth yang ditemukan pada sayur selada di beberapa pasar tradisional di Surabaya adalah hanya telur cacing Ascaris spp. Proporsi penjual dengan sayur terkontaminasi telur cacing STH cukup tinggi yang memerlukan perhatian pengelolaan kebersihan bahan pangan pada pasar tradisional.

\section{UCAPAN TERIMAKASIH}

Terimakasih ditujukan kepada Universitas Ciputra yang telah memberikan dana untuk penelitian ini. Terimakasih juga ditujukan kepada Mr. Mogaji Mohammad di Nigeria dan drh. Shafa di Pakistan, drh. Suhintam Pusarawati, M.Kes. dan DR. Sukmawati Basuki di Fakultas Kedokteran Unair, Prof. Dr. Setiawan Koesdarto, drh., M.Sc. di Fakultas Kedokteran Hewan Unair, Bapak Junus Widjaja dan Bapak Leonardo Taruk Lobo di Badan Litbang Kesehatan Kementerian Kesehatan RI atas bantuannya sharingnya dalam mengidentifikasi telur cacing yang meragukan.

Surabaya; 2015; pp. 1-2.

7. Anggianto D dan Handinoto. Grha Kuliner Khas Surabaya di Surabaya. Jurnal eDimensi Arsitektur. 2013; 2(2): 218-224.

8. Iskandar BS dan Sugiharto S. Analisa Pengaruh Faktor-faktor Service Quality terhadap Customer Satisfaction di Restoran Mr. Pancake Surabaya. Jurnal Manajemen Pemasaran. 2013; 1(1): 1-12.

9. Chau HLQ, Thong HT, Chao N Van, et al. Microbial and Parasitic Contamination on Fresh Vegetables Sold in Traditional Markets in Hue City, Vietnam. Journal of Food Nutrition Research. 2014; 2(12): 959-964.

10. Astuti R dan Aminah S. Identifikasi Telur Cacing Usus pada Lalapan Daun Kubis yang dijual Pedagang Kaki Lima di Kawasan Simpang Lima kota Semarang. Jurnal Universitas Muhammadiyah Semarang. 2008; 1(1): 297-307.

11. Dada EO and Makinde OO. Microbial and Parasitic Contamination on Vegetables Collected from Retailers in Main Market, Akure, Nigeria. American Journal of Microbiological Research. 2015; 3(3): 112-117.

12. Benti G and Gemechu F. Parasitic Contamination on Vegetables Irrigated with Awash River in Selected Farms, Eastern Showa, Ethiopia. Journal Parasitology and Vector Biology. 2014; 5(7): 103-109.

13. Mogaji H, Ekpo UF, Oluwole AS, Adeniran A, Mariam $\mathrm{F}$, and Alabi OM. Prevalence of Parasites Found on 
Vegetables, and Perception of Retailers and Consumers About Contamination in Abeokuta Area of Ogun State, Nigeria. Clinical Microbiology \& Case Reports. 2016; 2(1): 1-5.

14. Eraky MA, Rashed SM, Nasr MES, El-Hamshary AMS, and El-Ghannam SA. Parasitic Contamination of Commonly Consumed Fresh Leafy Vegetables in Benha, Egypt. Journal of Parasitology Research. 2014; 2014: 1-7.

15. Lobo LT, Widjadja J, Oktaviani, Octaviani NFN, dan Puryadi NFN. Kontaminasi Telur Cacing SoilTransmitted Helmints (STH) Pada Sayuran Kemangi Pedagang Ikan Bakar di Kota Palu Sulawesi Tengah. Media Penelitian dan Pengembangan Kesehatan. 2016; 26(2): 65-70.

16. Suryani D. Hubungan Perilaku Mencuci dengan Kontaminasi Telur Nematoda Usus pada Sayuran Kubis (Brassica oleracea) Pedagang Pecel Lele di Kelurahan Warungboto Kota Yogyakarta. Jurnal Kesehatan Masyarakat. 2012; 6(2):162-172.

17. Kattula D, Sarkar R, Ajjampur RSS, et al. Prevalence \& Risk Factors for Soil Transmitted Helminth Infection Among School Children in South India. The Indian Journal of Medical Research. 2014; 139(1): 76-82.

18. Anbumani $\mathrm{N}$ dan Mallika $\mathrm{M}$. Prevalence and Distribution of Soil Transmitted Helminths (STH) among Asymptomatic School Going Children in South Chennai, Tamil Nadu, India. International Journal of Medicine and Public Health. 2011; 1(2): 57-59.

19. Resnhaleksmana E. Prevalensi Nematoda Usus Golongan Soil Transmitted Helminthes (STH) pada Peternak di Lingkungan Gatep Kelurahan Ampenan Selatan. Media Bina Ilmiah. 2014; 8(5): 45-50.

20. Tefera T, Biruksew A, Mekonnen Z, and Eshetu T. Parasitic Contamination of Fruits and Vegetables
Collected From Selected Local Markets of Jimma Town, Southwest Ethiopia. International Scholarly Research Notices. 2014; 2014: 1-7.

21. Sunil B, Thomas DR, Latha C, and Shameem $H$. Assessment of Parasitic Contamination of Raw Vegetables in Mannuthy, Kerala State, India. Veterinary World. 2014; 7(4): 253-256.

22. Olyaei A and Hajivandi L. Parasitological Contamination of Markets and Farms in Vegetables Consumed in Southern Iran. Global Veterinaria. 2013; 10(3): 327-331.

23. Alsubaie ASR, Al-Mekhlafi AMK, Al-Shibani LAN, AlEryani SMA, and Azazy AAA. Hygienic Assessment of Pathogenic Contamination in Raw Vegetables in Local Markets: An Implication for Public Health. International Research Journal of Microbiology. 2014; 5(2): 16-21.

24. Leles D, Gardner SL, Reinhard K, Inguez A, and Araujo A. Are Ascaris lumbricoides and Ascaris suum A Single Species? Parasit Vectors. 2012; 5(42): 1-7.

25. Liu GH, Wu CY, Song HQ, et al. Comparative Analyses of The Complete Mitochondrial Genomes of Ascaris lumbricoides and Ascaris suum from Humans and Pigs. Gene. 2012; 492(1): 110-116.

26. Ginting C. Kajian Biologis Tanaman Selada dalam Berbagai Kondisi Lingkungan pada Sistem Hidroponik. Jurnal Agriplus. 2010; 20(2): 107-113.

27. Hairani B, Waris L, dan Juhariyah. Prevalensi Soil Transmitted Helminth (STH) pada Anak Sekolah Dasar di Kecamatan Malinau Kota Kabupaten Malinau Provinsi Kalimantan Timur. Jurnal Buski. 2014; 5(1): 43-48.

28. Loganathan R, Agoes R, and Arya IFD. Vegetables Contamination by Parasitic Helminth Eggs in Malaysia and Indonesia. Althea Medical Journal. 2016; 3(2): 190-194. 